\title{
A PLACE WITH SHARED MEANINGS: MITHRAS, SABAZIUS, AND CHRISTIANITY IN THE "TOMB OF VIBIA"
}

\begin{abstract}
Summary: Recent research has increasingly questioned the "grand dichotomy" between "Paganism" and Christianity and brings into light the prominence of spaces with shared meanings in diverse cults related to mystic beliefs and practices. An excellent example is Vibia's tomb within Praetextatus'catacomb, on the Via Appia. Dated to the 4th century AD, this place combines epigraphy and a fascinating iconography pointing to a mystic initiation of the deceased within a syncretic context.
\end{abstract}

Key words: Pagan and Christian burials, initiation, interpretatio, syncretism, Mithras, Sabazius, otherwordly judgment, celestial banquet

\section{THE CONTEXT OF THE CEMETERY}

The so-called "tomb of Vibia" is a hypogaeum that was found in the 18 th century by G. C. Bottari, and then fell into oblivion, to be re-discovered at the end of this century by the Jesuit father G. Marchi, who included it within the catacombs of Pretextatus. The most complete study of the complex (situated at 101, Via Appia) was made by Antonio Ferrua, who excavated it in 1951-52, and then again in 1971 and 1973 , although the most detailed description of the pictorial panels remains, to this day, the one given by Garrucci in his 1852 publication. ${ }^{1}$

${ }^{1}$ GARRUCCI, R.: Tre sepolcri con pitture e iscrizioni appartenenti alle superstizioni pagane del Bacco Sabazio, e del Persidico Mitra scoperti in un braccio del cimitero di Pretestato in Roma. Napoli 1852; Nilsson, M. P.: À propos du tombeau de Vincentius. In Mélanges Ch. Picard. Vol. II. Paris 1949, 746-769; FERrUA, A.: La catacomba di Vibia. RAC 47 (1971) 7-62 and RAC 49 (1973) 131-161, with references; LANE, E. N. (ed.): Corpus Cultus Iovis Sabazii. Vol. 2: Other Monuments and Literary Evidence [Études préliminaires aux religions orientales dans 1' Empire]. Leiden 1986, 31-32, nr. 65, pl. XXVII; Demarsin, K.: Paganism in Late Antiquity: Thematic Studies. In LAVAN, L. - MulRYAN, M. (eds): The Archaeology of Late Antique 'Paganism'. Leiden-Boston 2011, 3-40, here 39-40. 
This private cemetery is made up of seven different hypogaea that were only interconnected in the late period, when they were gradually excavated to find new burial spaces. The arcosolium where Vibia and her supposed husband, Vincentius, were buried, in gallery V3, corresponds to the deepest level of the complex - that is, to its last phase, datable to the second half of the 4th century.

In the same gallery, another interesting arcosolium appears opposite Vibia's. This is the so-called "Arcosolium of the Mysteries" and displays paintings with diverse human figures - some of them soldiers which have been associated with the miles grade within the Mithraic cults; an inscription in a nearby arcosolium mentions Mithras himself. ${ }^{2}$ The verification of the contiguity of these tombs caused great interest because it pointed to the co-existence within the same hypogaeum of pagan and Christian burials. While some researchers, such as Bottari, repudiated such a possibility, judging that the whole complex had a Christian identity, Marchi accepted this contiguity, although he assumed that walls existed between the two types of tomb, because blocks were discovered in front of the Arcosolium of the Mysteries. Ferrua's works, however, have demonstrated that gallery V3 was not divided, but continued with other tombs, some pagan and some Christian; of these, most notable are a monumental space (Va) with Christian tombs, as well as gallery V6, which is more recent, with pictures on an arcosolium representing wine transportation. ${ }^{3}$

In gallery V4, which continues on from V3 where Vibia's tomb is located, a great Proconnesian marble inscription was found, belonging to another arcosolium, mentioning two Aurelii, Fautinianus and Castricius, sacerdotes of the Deus Sol Invictus Mithra. ${ }^{4}$ This second inscription implies a family of Mithraic cultores of at least five members, and contains formulae which are typical in Christian epigraphy, such as bona memoria. Both Mithraic inscriptions question Cumont's thesis that the cults of Sabazius and Mithras could not go together in the same funerary space.

\section{"VIBIA'S TOMB"}

The existing images and didascalic texts which explain the meaning of the scenes can be read together as a programme developed through several phases. On the semi-circular

\footnotetext{
${ }^{2}$ Standing male figures are depicted on both sides of the arcosolium, with a large garland hanging from two kraters between them, judging by the drawing by GARRUCCI (n. 1) 84. In the interior, the panel on the left shows another two male figures, one standing and one sitting (the latter, with helmet, spear, and sword, his torso bare, would represent Mars). The central painting shows two winged Erotes bearing branches of trees, flanking a space which would have held a painted inscription, of which little now remains. The panel on the right contains a kneeling soldier with a sword and shield, and another apparently female figure, also kneeling, wears a leafy headdress. The ceiling of the arcosolium depicts Venus seen in rear view, with images of peacocks, dolphins, and the head of Ocean (GARRUCCI [n. 1] 86 and 88). The text reads: $D$ (is) M(anibus) / M(arcus) Aur[---] s(acerdos)d(ei) S(olis) I(nvicti) M(ithrae) / qui bas[i]a [v]oluptatem iocum alumnis suis dedit / ut locu[---] e et natis suis / [---] en locus carici / [---] so proles (GARRUCCI [n. 1] 88).

${ }^{3}$ FERRUA (n. 1) 7-27, with a very thorough review of the studies' historiography.

${ }^{4}$ FERRUA (n. 1) 44: Diis) M(anibus). Sanctae adquae peraenni bone memoriae viris Aurelii[s] Faustiniano patri, et Castricio fratri, sacerdotibus Dei Solis Invicti Mithrae, eredes aeorum prosecuti sunt, e[t] b(onae) m(emoriae) Clodia Celerianae matrif(ecerunt).
} 


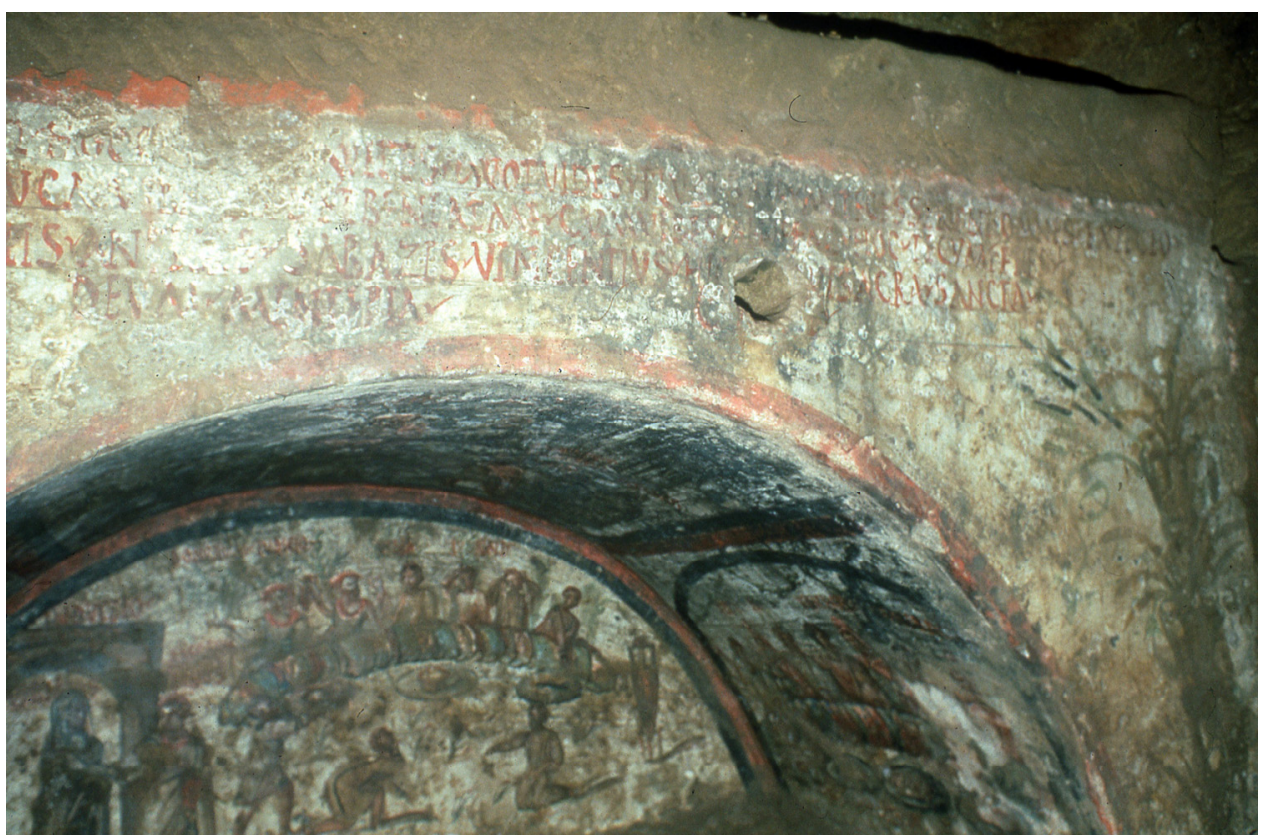

Plate 1. The arcosolium with the Inscription of Vincentius (photo of Archivio Fotografico della Pontifica Commissione di Archeologia Sacra)

arcosolium, in the interior of which unfold dazzling scenes accompanied by didascalic texts, appears the magnificent four-line painted inscription about Vincentius ${ }^{5}$ (pl. 1; fig. 1). The inscription and images are flanked on each side by vertical motifs of a stem with four palmettes, from which spring phytomorphic motifs, with a further tendril curling from and around each stem.

5 [Vi]ncenti hoc o[stium] quetes quot vides; plures me antecesserunt, omnes expecto;/ Manduca, vibe, lude et beni at me: cum vibes, bene fac, hoc tecum feres. / Numinis antistes Sabazis Vincentius hic e[st q] ui sacra sancta / deum mente pia co[lui]t. On 7th September 2016, I visited the catacomb accompanied by Professor Giulia Sfameni Gasparro and Dr Raffaella Giuliani, of the Pontificia Commissione di Archeologia Sacra, whom I warmly thank for her assistance in accessing this remarkable place, as well as for sending me Garrucci's text. I also thank my colleague Dr Marina Piranomonte for having provided, with her usual efficiency and kindness, the contacts that made this visit possible. Our katabasis into the fascinating space that holds Vibia's Tomb allowed us to carry out an examination that ascertained the flawed organisation of the texts in $C I L$, repeated in the other epigraphic corpora, which have unnecessarily divided this inscription and interspersed it among some of the texts that accompany the images in the arcosolium's interior. The same entry in CIL includes the inscription mentioning the priest of Sol Invictus Mithrae, as well as the texts that accompany the paintings of Vibia and Vincentius. CIL VI 142 (p. 3775 $=$ CLE $1317=I L S 3961=$ D $3961=$ AIIRoma 11, $39=$ EDCS-17200234: Dis pater Aeracura $/$ Fata divina / Mercurius / Nuntius / Vibia Alcestis // Abreptio Vibie(a)s(!) et discensio // septe(m) pii sacerdotes / Vincentius // Bonorum iudicio iudicati / Vibia // Angelus / bonus // Inductio / Vibi(a)es(!) // [Vi]ncenti hoc o[stium(?)] qu(i)et $<i=E>_{S}$ quo $<d=T>$ vides plures me antecesserunt omnes expecto // Manduca $<b=V>$ ibe lude $e(t)<v=B>$ eni $a<d=T>$ me cum $v i<v=B>$ es bene fac hoc tecum feres / Numinis antistes Sabazis Vincentius hic e[st q] ui sacra sancta / deum mente pia co[lui]t // D(is) M(anibus) / M(arcus) Aur[3] s(acerdos) d(ei) S(olis) I(nvicti) M(ithrae) / qui bas[i]a [v]oluptatem iocum alumnis suis dedit / ut locu[3] e et natis suis / [3] en locus carici / [3] so proles. 


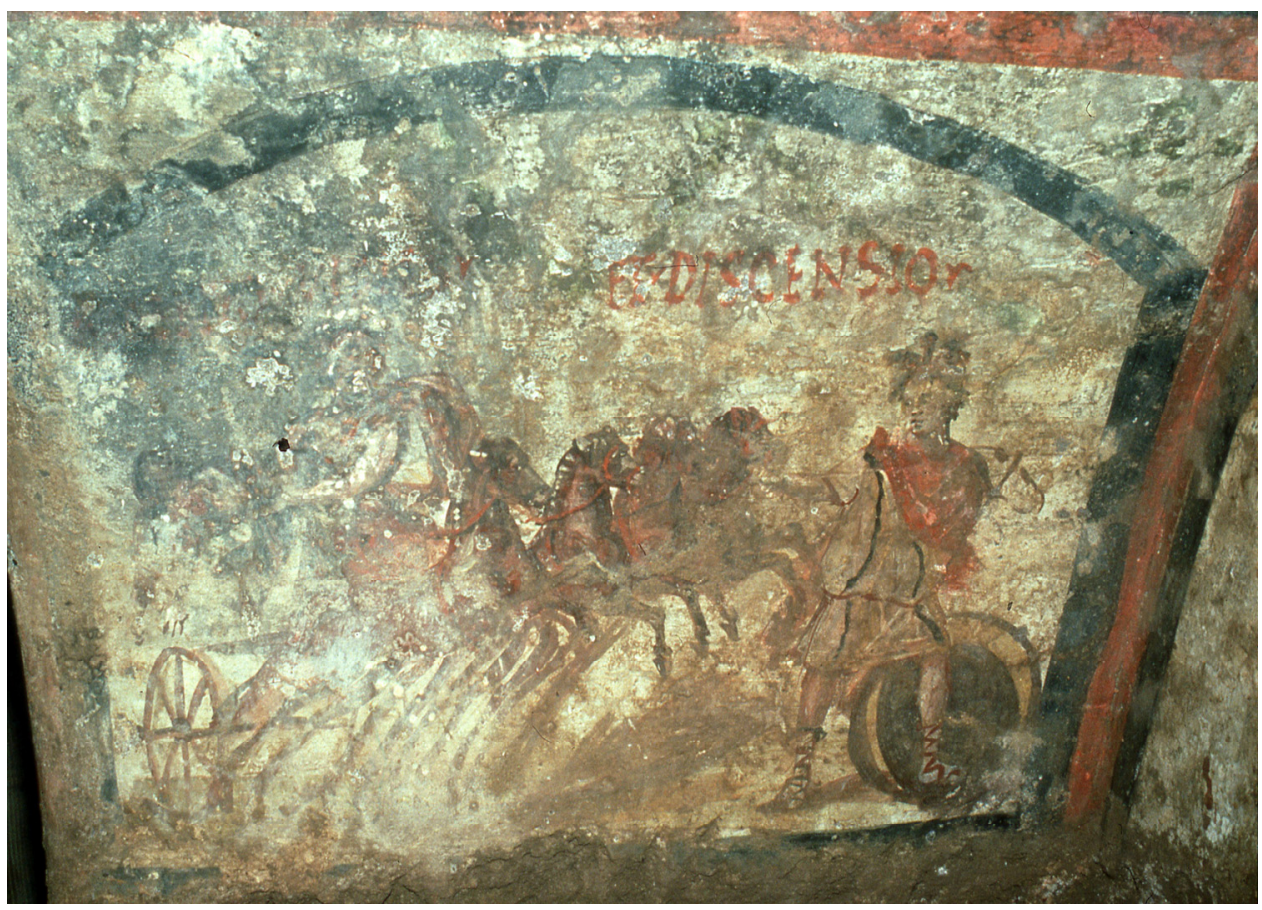

Plate 2. Vibia's Kidnapping (photo of Archivio Fotografico della Pontifica Commissione di Archeologia Sacra)

The interior of the arcosolium contains a series of painted panels that should be read from left to right:

a) Firstly, in the left-hand panel, Vibia is kidnapped by the god of the Underworld (in an iconography typical of the Eleusinian mysteries) and taken in a quadriga to Hades, with Mercury Psychopompus guiding the pair, presumably to a chasm into the earth (pl. 2). The deity steps forward with his left leg, behind which there is an object that has been interpreted by Garrucci as a dolium with its mouth turned towards the viewer, and seems to represent a container of wine. ${ }^{6}$ Hades embraces Vibia's body, whose own arms hang down as if she were lifeless. Above the scene, there is the inscription alluding to Vibia's kidnapping ${ }^{7}$ and the descent to the underworld: Abreptio Vibies(!) et discensio.

b) Secondly, in the panel on the arcosolium ceiling, Vibia is introduced to the underworld by Mercurius Nuntius and Alcestis ${ }^{8}$ before the tribunal of Dis Pater and

${ }^{6}$ GARRUCCI (n. 1) 6, 16-18, according to whom the mouth of the dolium would represent access to Hades itself. In other contexts, this was represented by fluvial figures, or by the Naiad of a spring, Cyane, who was sometimes represented by a krater (Ovid. Met. $5.413 \mathrm{ff}$.).

${ }^{7}$ The image of abduction as a metaphor for death at a young age, also apparent in the funerary inscriptions of maidens described as raptae, was something already pointed out by GARRUCCI (n. 1) $14 \mathrm{ff}$.

${ }^{8}$ Quint. Decl. 9: Una finguitur conjunx, quae iam perituri vitam coniungis vicaria morte sua redemit. Alcestis was a model of conjugal love, whose wonderful sacrifice to save her husband Admetus 


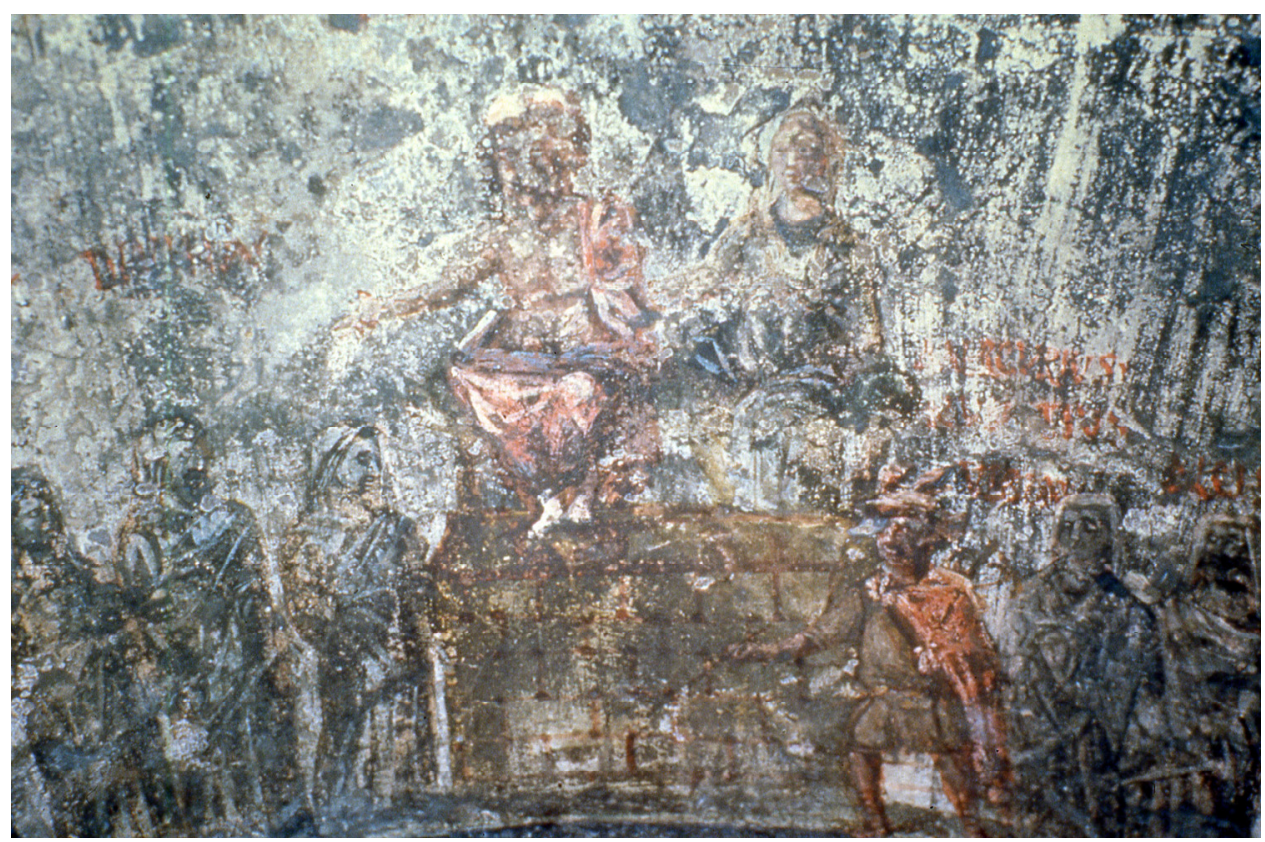

Plate 3. Scene of Vibia's Judgment (photo of Archivio Fotografico della Pontifica Commissione di Archeologia Sacra)

Aeracura, the infernal deities, depicted sitting in an eminent position and addressing their right hands to the court formed by three female veiled figures, ${ }^{9}$ the Fata Divina, attending the scene on the left of the composition (pl. 3; fig. 3). A didascalium accompanies each of the characters represented in this composition illustrating the final judgement of the deceased. It has been suggested that Mercurius Nuntius and Alcestis represent the defenders of the deceased and the Fata Divina their accusers, ${ }^{10}$ although they seem to be, respectively, the deities which introduce them, and which form the members of their subterranean tribunal, in proceedings whose ultimate sanction naturally corresponds to Dis Pater and Aeracura. ${ }^{11}$

- her voluntary descent to the underworld - was recognised by the gods, who granted her a new life, rescued by Hercules. See Eur. Alc. passim; Plat. Symp. 179C; Hig. Fab. 51; Diod. 4. 52. 2; Apollod. Bibl. 1. 9. 15 .

${ }^{9}$ From the drawing by GARRUCCI (n. 1) 80, some authors have followed his interpretation: the painting would represent two female figures (the Parcae) and a central, bearded male figure, Fate, son of Erebus and Night (GARRUCCI [n. 1] 18-19.

${ }^{10}$ VelAZA, J.: Interpretatio y sincretismo en los CLE: algunos casos singulares In GÓMEZ I FONT, X. - FERnÁNDEZ MARTíneZ, C. - GóMEZ PALlARÉs, J. (eds): Literatura epigráfica: estudios dedicados a Gabriel Sanders. Zaragoza 2009 331-351, here 337-339.

${ }^{11}$ On Eracura as an interpretatio of Proserpina, see infra. A text by Claudian (de raptu Proserpinae 50. 2. $302 \mathrm{ff}$.) records the promise made by the god of the Underworld to Proserpina to let her rule the Parcae: Tu damnatura nocentes, / tu requiem latura piis, te judice, sortes / improba cogantur vitae commissa fateri. / Accipe lethaeo famulas cum gurgite parcas, / sit fatum quodque voles (see GARRUCCI [n. 1] 18). 


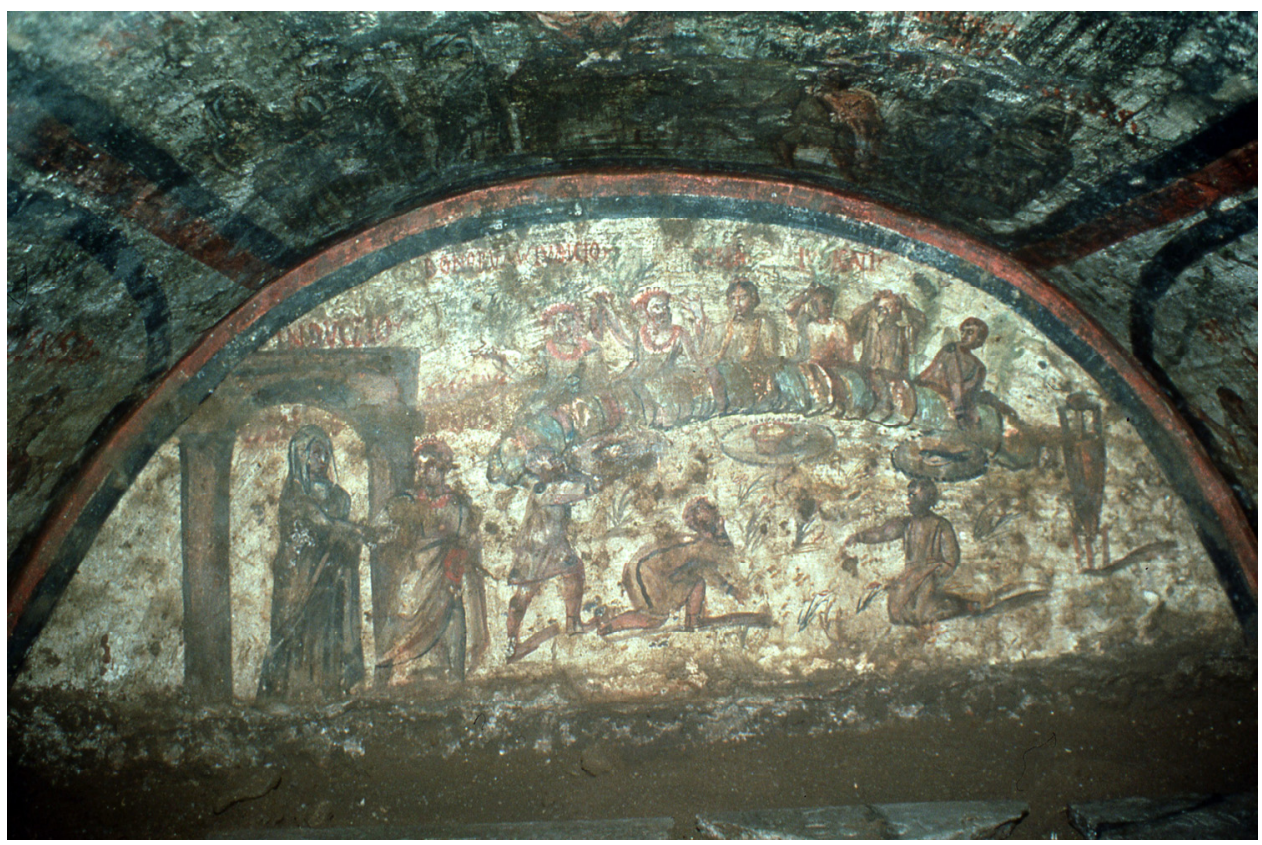

Plate 4. The Otherwordly Banquet (photo of Archivio Fotografico della Pontifica Commissione di Archeologia Sacra)

c) Judgment is passed, and in the third and central scene, painted in the lunette on the rear wall, Vibia is introduced by an Angelus Bonus, depicted with toga, floral garland around her neck, and crown, to an otherworldly banquet which she will share with other blessed souls (pl. 4). Access is through an arch with the inscription Inductio Vibies above and below the structure. There are six blessed figures of different ages and gender, Vibia being the third on the left; they are depicted reclining before the celestial banquet they are enjoying with their left elbows resting on a soft, curved low wall - similar to a long cushion - in the shape of a $\mathrm{C}$, for which reason it is called sigma. The didascalia on the figures are clear: Bonorum Iudicio, Vibia and Iudicati ("those approved by the judgement of the good"); the background behind the revellers depicts a landscape with small trees or branches, and a meadow in front of which three attendants appear. One of them is holding a large dish containing what seems to be a goose or hare, and two other big dishes are on the ground with a vessel like a calathus, a basket or large loaf, and a fish. Two other kneeling figures represent other assistants, and a large amphora on a wooden base also appears on the right.

This scene of heavenly banquet is easily understandable from a Christian perspective (including the fish as the food depicted in the painting). ${ }^{12}$ If the banquet scene

\footnotetext{
${ }^{12}$ Christian eucharistic banquets appear in the catacombs of Callistus, Priscilla (3rd cent.) and the saints Peter and Marcellinus (BAUDRY, G.-H.: Les symboles du christianisme ancien: Ir $^{e}$-VII siécle. Paris 2009 , 201, fig. 2; 202-203, figs 1-3; 224, fig. 1). For the convivium as a symbol of the heavenly banquet,
} 


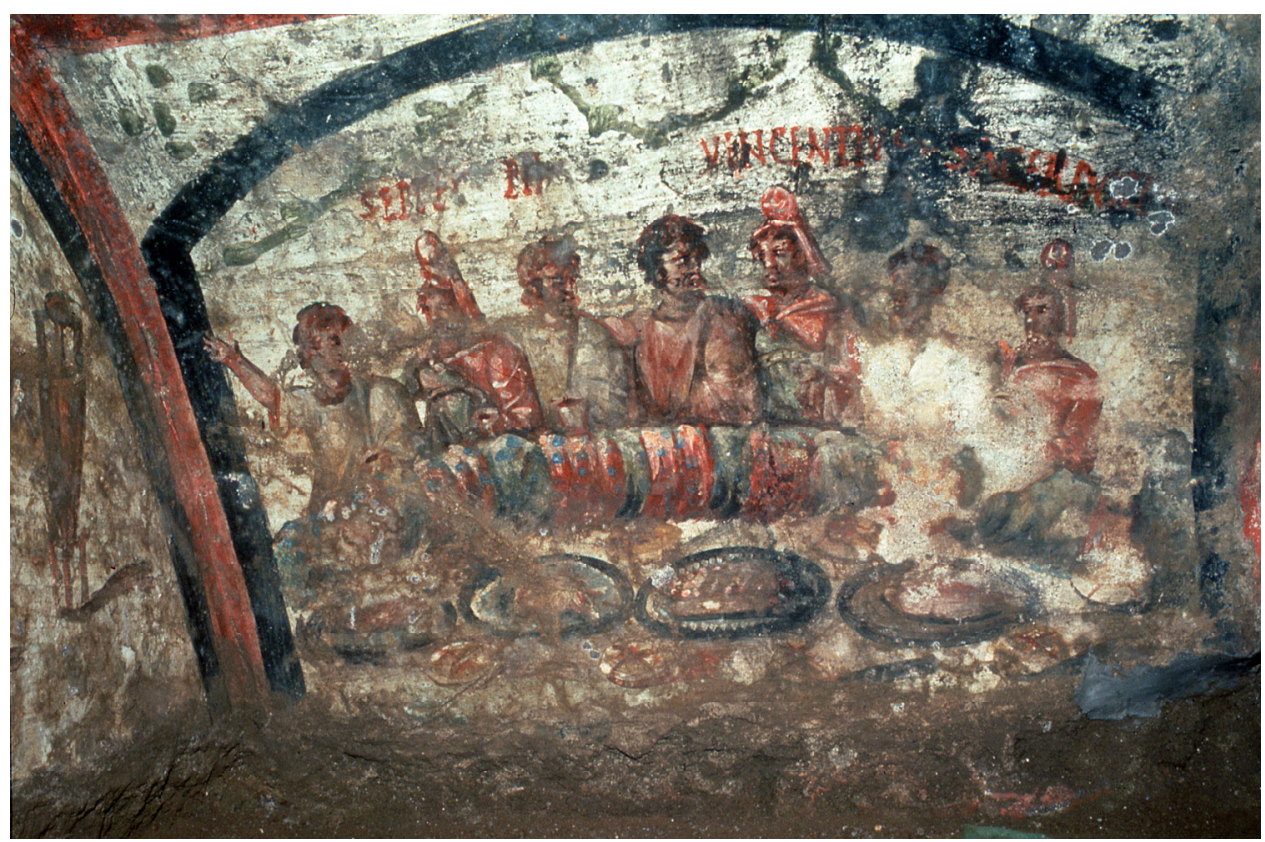

Plate 5. Vincentius' Banquet (photo of Archivio Fotografico della Pontifica Commissione di Archeologia Sacra)

shows six diners waiting for Vibia to make up the seventh at their party, ${ }^{13}$ the total number of seven would match that of the diners on Vincentius' fresco.

d) Finally, there is another scene painted on the right side of the arcosolium, with a banquet iconography similar to the previous, central one (pl. 5). The paintings in Vincentius' fresco seem to have been made by the same hand, and the scene is very similar to the last of Vibia's sequence: seven characters, male and female, participate in a banquet, with eight tetrabloni loaves with crosses drawn across them which divide them into four parts, and four large dishes containing a fish, a loaf or pie, a hare and a goose. Over the figures, beneath a garland of flowers, an inscription mentions the Septem pii sacerdotes and Vicentius. This homogeneity of style and content, as well as the contiguity of the images, suggests Vincentius is the husband of Vibia.

Of the seven sacerdotes, the first three hold cups, and the last one a loaf. The fact that three of the seven also wear special garments of a more eastern style, and particularly that they wear Phrygian caps (including Vincentius, who is the fifth figure from the left, if we may extrapolate from the position of the inscription with his name),

see Mt 8.11: "And I say unto you, That many shall come from the east and west, and shall sit down with Abraham, and Isaac, and Jacob, in the kingdom of heaven" (KJV); see also Mc 14.25 and Is 25.6.

${ }^{13}$ JENSEN, R. M.: Understanding Early Christian Art. London - New York 2000, 55. 


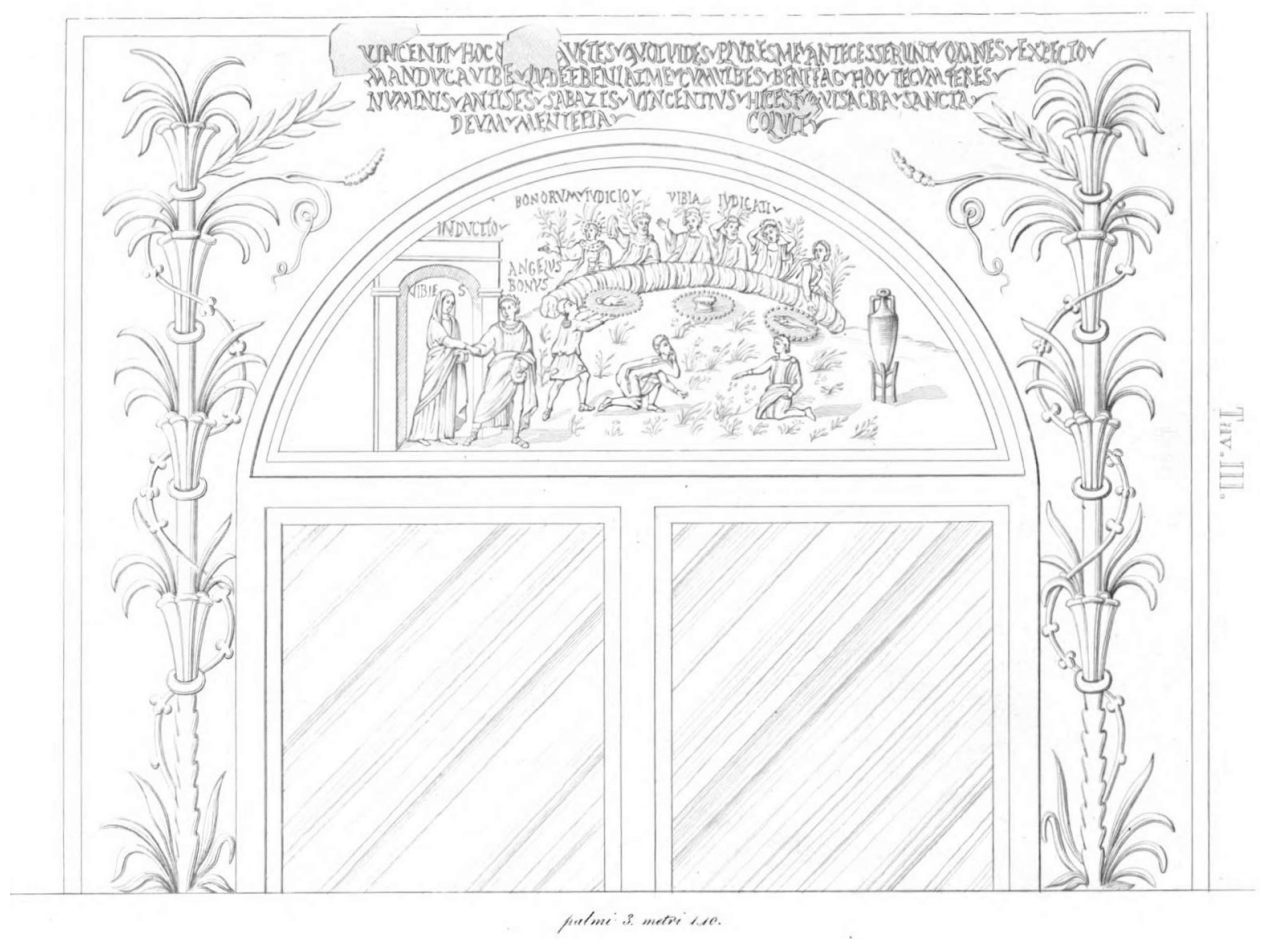

Fig. 1. The arcosolium's Front (after GARRUCCI [n. 1] 82)

raises the possibility that two different grades within this priestly college are represented. Vincentius, along with the first figure on the left, is the only one without a beard, but he appears as an antistes in the inscription painted on the arcosolium, and it is possible that this grade (higher?) is represented by the Phrygian cap, which is also worn by the figures who are second from the left, and far right: these would constitute the three primi sacerdotes, as Garrucci has previously claimed. ${ }^{14}$

In the inscription above the tomb, Vincentius, antistes of Sabazius, issues an invitation to enjoy a blessed life, which corresponds with the central pictorial panel that describes Vibia's adventus to Elysium and her participation in the heavenly feast alongside the other blessed souls (pl. 1; fig. 1). The same theme is celebrated in two ways on the frontal of the arcosolium: Vincentius' inscription (at the top) and Vibia's apotheosis in the central picture (beneath it). It can also be assumed, given the order of the paintings, that Vibia died first, at a very young age, followed later by Vincentius, who was interred in the same place.

${ }^{14}$ GARRUCCI (n. 1) 34. 


\section{A SYNCRETIC HORIZON OF SHARED MEANINGS}

All this represents a syncretic ${ }^{15}$ horizon of shared meanings among different cults and between pagans and Christians. The extraordinary iconography of Vibia's tomb displays a cinematographic sequence illustrating the process of death understood as the woman's kidnapping by Pluto and her descent to the other world, the judgement of the deceased and her entry into Elysium to take part in the celestial banquet. All this occurs in a syncretic horizon (that is more "utopian" than "locative", according to the categories established by Smith) ${ }^{16}$ where several elements are mixed. On the one hand, there is Greek mythology; on the other, the assimilation of Proserpina to the Celto-Germanic deity Eracura; thirdly, there is a clear mystic component through the Sabazius cult; and finally, the attestation of elements of presumably Christian influence. A similar syncretism is confirmed in other contexts with a similar chronology: for example, the sanctuary of Anna Perenna, where pagans and Christians shared the ritual space, demonstrated not only by the presence of Christians lamps, but also by a newly discovered copper defixio mentioning Christum nostrum... deas vestras; or by the association of the iconography of Abraxas with Jesus Christ, as Németh has recently shown. $^{17}$

The myth of the abduction of Proserpina (pl. 2; fig. 2), which underpins the Eleusinian Mysteries and their messages of a "better hope" after death, ${ }^{18}$ is often represented from the 4th century on pottery in tombs, above all in the Eastern part of the Graeco-Roman world. ${ }^{19}$ The myth became a speaking image which evokes a cosmo-

\footnotetext{
${ }^{15}$ Some studies question the use of the term "syncretism", observing that all the religious systems in the Ancient World contain some elements from different cultural contexts; instead they prefer the term "assimilation" (thus DrIJVERS, H. J. W.: Cults and Beliefs at Edessa [EPRO 82]. Leiden 1980, 17-18: "A culture assimilates other elements to its own tradition and pattern, but does not mingle or mix everything together.") Various contributions to the field of anthropology and social sciences have, nevertheless, recently defended its appropriateness: PYE, M.: Syncretism versus Synthesis, British Association for the Study of Religions [Occasional Papers 8]. Cardiff 1993; STEWART, C. - SHAW, R. (eds): Syncretism/Antisyncretism. The Politics of Religious Synthesis. London - New York 1994; AJMER, G.: Syncretism and the Commerce of Symbols. Göteborg 1995; BONNET, C. - MOTTE, A. (eds): Les syncretismes religieux dans le monde méditerranéen antique. Actes du Colloque International en l'honneur de Franz Cumont à l'occasion du cinquantième anniversaire de sa mort. Rome, Academia Belgica, 25-27 septembre 1997. BruxellesRoma 1999. The distinction made between kinds of syncretism may be interesting: unequivocal syncretism (such as that of bilingualism or the genuinely compound deities, such as those of the hierothesion of Antiochus I in Nemrud Dag: See ADRYCH, P. - BRACEY, R. - DALGLISH, D. - LENK, S. - WOOD, R., Images of Mithra. Oxford 2017, 128-157), "embedded syncretism" (depicting a deity with a name from one cultural tradition with the requisites of a deity from another cultural tradition), and academic syncretism (KAIZER, T.: Identifying the Divine in the Roman Near East. In BRICAULT, L. - BONNET, C. (eds): Panthée: Religious Transformations in the Graeco-Roman Empire. Leiden-Boston 2013, 113-128, here 115-116.

${ }_{16}^{16}$ SMITH, J. Z.: Map is not Territory. Studies in the History of Religions. Leiden 1978.

${ }^{17}$ Piranomonte, A.: The Discovery of the Fountain of Anna Perenna and Its Influence on the Study of Ancient Magic. In BAKOwSKA-CZERnER, G. - RocCATTI, A. - SWIERZOWSKA, A. (eds): The Wisdom of Toth: Magical Texts in Ancient Mediterranean Civilisations. Oxford 2016, 71-85.

${ }_{18}$ Cic. Leg. 2. 14. 36: spes melior moriendi.

${ }^{19}$ GuIMIER-Sorbet A.-M. - SEIF EL-DIN, M.: Les deux tombes de Perséphone dans la nécropole de Kom esch Chougafa à Alexandrie. Bulletin de Correspondance Hellénique 121 (1997) 386-389. This is an exceptionally interesting example. In two superposed registers, the fate of humanity after death is
} 


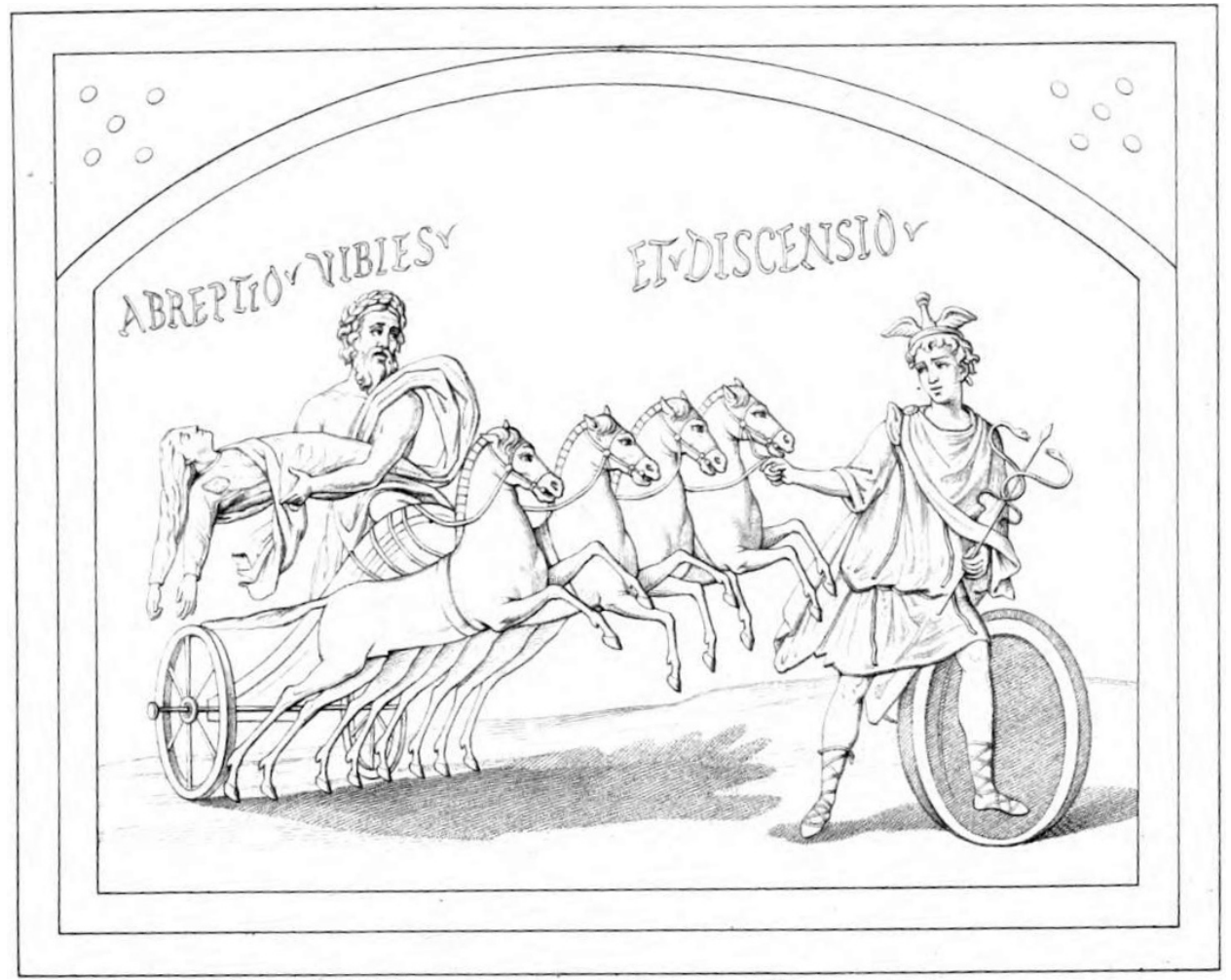

Fig. 2. Vibia's Kidnapping (after GARRUCCI [n. 1] 78)

politan eschatological structure (parallel to the Egyptian one of Osiris' embalming - the prototype for the Osirification of the deceased, with all its eschatological significance); and as such it was open to people of different national, social, and cultural identities. This, then, is the meaning of abduction in the famous Roman tomb. ${ }^{20}$

The appearance of Alcestis beside Mercury, the two characters who introduce Vibia in the judgement of our fresco (pl. 3; fig. 3), is also attested in a sarcophagus from Aquileia, possibly from the beginning of the 3 rd century. ${ }^{21}$ A Roman tomb in the Via Latina datable between 160 and 170 also includes a pair of paintings with Alcestis. In one of them, Hercules brings Alcestis back to her husband Admetus, king of Feras in Thessaly, in the presence of Athena. The other scene from the same

evoked in Egyptian terms (above: the resurrection of Osiris thanks to Anubis and Isis), and in Greek terms (below: Persephone's descent to the underworld following her abduction by Hades): DUNAND, F.: Images des dieux en dialogue. In BRICAULT-BONNET (n. 15) 191-232, here 198, fig. 4.

${ }^{20}$ Sfameni Gasparro, G.: Aprés Lux Perpetua de Franz Cumont: quelle eschatologie dans les ‘cultes orientaux' á mystères? In BRICAULT-BONNET (n. 15) 245-267, here 265.

${ }^{21}$ SCHMIDT, M.: Alkestis. In Lexikon Iconographicum Mythologiae Classicae [LIMC] I/1 (1981) 539 , nr. 49. 


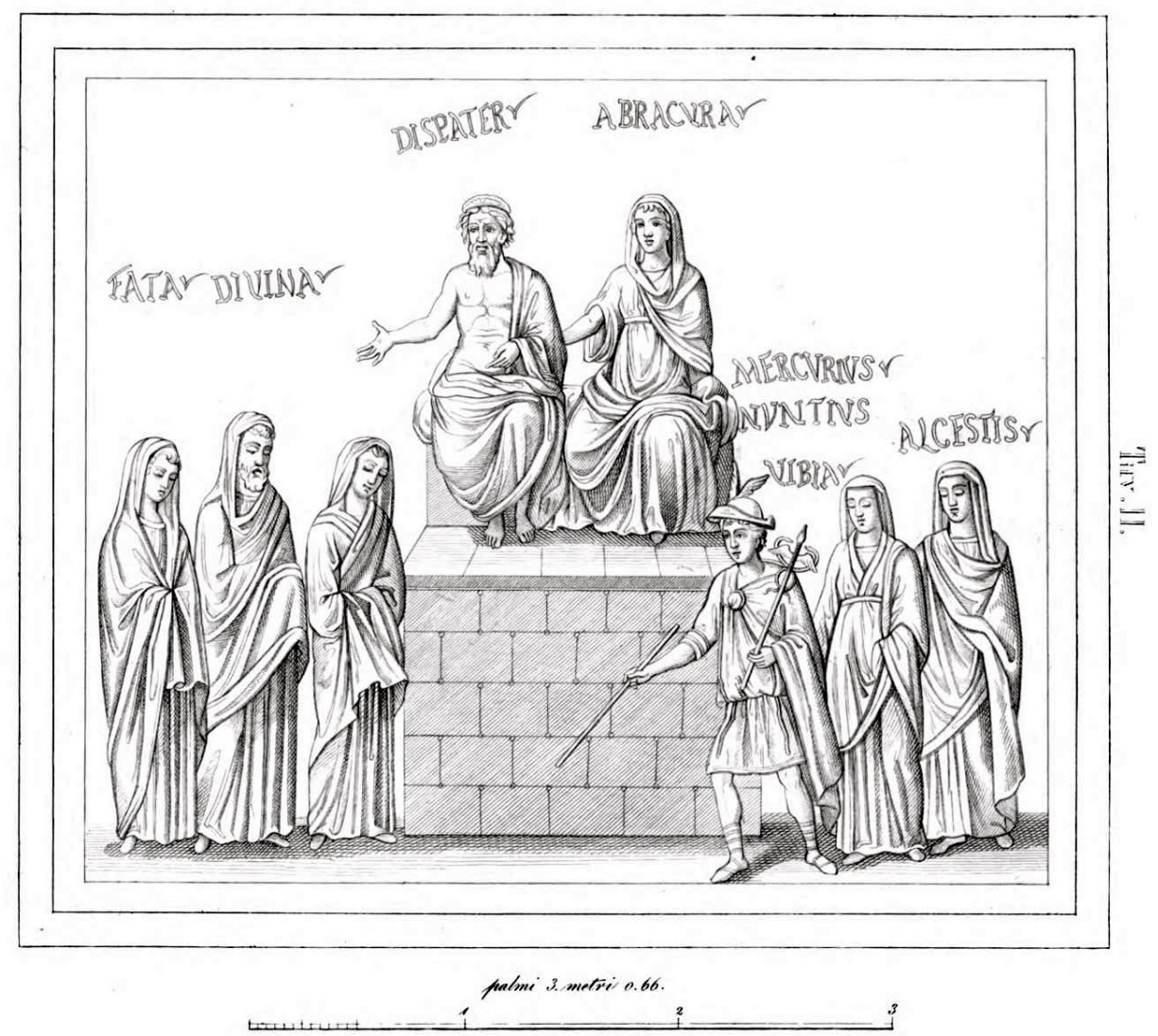

Fig. 3. Vibia's Judgment (after GARRUCCI [n. 1] 80)

tomb, however, is of greater interest to us, since Mercury and Alcestis are introducing the deceased - in this case a young figure - to the infernal couple, as in Vibia's tomb. ${ }^{22}$ Alcestis, one of the daughters of Pelias, king of Yolco, is a prototype of conjugal love, to the extent that she offered herself to die instead of her husband (see above n. 8). Hercules, however, brought her back to the Earth (in other versions, Persephone, impressed by Alcestis' abnegation, sent her to the living world). This is the mythical background that explains the appearance of Alcestis in the funerary scenes, as the prototype of an intermediary between this world and the Beyond, and her introductory function together with Mercurius Nuntius, Mercury the Messenger.

The three Fata appearing in the scene of the judgement are also represented on an altar from Avignon (Calvet Museum) dedicated by one Cornelius [Ach]il[---], as

${ }^{22}$ SCHMIDT (n. 21) 540, fig. 51; BERG, B.: Alcestis and Hercules in the Catacomb of Via Latina. Vigiliae Christianae 48.3 (1994) 219-234. 
well as on aurei from Cizicus and Antiochia from the Diocletian period (284-286). ${ }^{23}$ Three female busts appear capitis velatis in a funerary cippus from Valencia, with the inscription Fatis / Q. Fabuus / Nysus / ex voto. ${ }^{24}$ It is possible that the pattern of distribution of the Tria Fata in western provinces such as Hispania, Gallia, or Pannonia could be explained through their assimilation with some local goddesses of the type of the Matres or Matronae.

The interpretatio ${ }^{25}$ of the infernal goddess through Aeracura, a Celto-Germanic deity, is another of the most interesting features of Vibia's tomb. Two representations of Herecura from Cannstatt (Germany) portray her sitting and holding a basket of fruit in her lap, following the typical iconography of the Matres or Matronae. The spelling of the goddess represented beside Dis Pater varies greatly: Aeraecura, Aericura, Aerecura, Erecura, Ercura, Eracura, Ericura and Herecura, Herequra. ${ }^{26}$ She is mentioned in altars from the south-west of Germany, the Netherlands, France (HauteMarne and Ain), Rome, Aquileia and Perugia, besides Romania and Algeria. ${ }^{27}$

According to Jona Lendering, ${ }^{28}$ Herecura's cult appears to be Illyrian and to have originated in the country north of the Adriatic Sea, where she and the death god (Dis Pater or Sucellus) were jointly venerated in Aquileia. ${ }^{29}$ Later, Roman soldiers took her cult across the Alps to Germania Superior and Raetia.

In an altar from Sulzbach, near Karlsruhe (Germany), found in a cave in 1981, Herecura is represented beside the god Dis Pater. While the goddess wears a long robe and bears a tray of fruit in her lap, the god wears a tunic and holds in his hands what seems to be an unrolled scroll. ${ }^{30}$

As Dis Pater was not only the god of fertility and agriculture, but also the god of the realm of the Dead, Herecura was also linked to death and endowed with a fu-

${ }^{23}$ SORDA, R.: Fata. In LIMC VIII/1 (1997) 581, with references; VIII/2, 362, fig. 2.

${ }^{24}$ CIL II 3727.

${ }^{25}$ On the variety of processes of interpretatio, both Graeca, and Romana, as well as indigena, within the context of the relationship between global and local, see the diverse contributions in CHIAI, G. F. HÄUSSLER, R. - KUnST, C. (eds): Interpretatio. Religiöse Kommunikation zwischen Globalisierung und Partikularisieung [Mediterraneo Antico 14]. Firenze 2012.

${ }^{26}$ JUFER, N. - LugINBÜHL, T.: Répertoire des dieux gaulois. Les noms des divinités celtiques connus par l' épigraphie, les textes antiques et la toponymie. Paris 2001. The meaning of the theonym remains obscure and is thought to be Celtic. X. DELAMARRE (Noms de personnes celtiques dans lépigraphie classique. Paris 2007, 13-14, 221) proposes *Eri-cura, "West Wind" while G. OLMSTED (The Gods of the Celts and the Indo-Europeans. Budapest 1994, 303-304) thinks that the name would mean "Before the Bread". For other scholars, however, Eracura has a Germanic origin (LINCKENHELD, E.: Sucellus et Nantosuelta'. Revue d'histoire des religions 99 [1929] 40-92, here 49; DE VRIES, J.: La Religion des Celtes. Paris 1963, 89; GREEN, M.: The Gods of the Celts. Sparkford 2004, 124; BECK, N.: Goddesses in Celtic Religion. Cult and Mythology: A Comparative Study of Ancient Ireland, Britain and Gaul. $\mathrm{PhD}$ thesis, Université Lumière Lyon 2, École doctorale: lettres, langue, linguistique, arts. (http://theses.univlyon2.fr/documents/lyon2/2009/beck_n\#p=0\&a=title) (Retrieved 1st October 2015) 135.

${ }^{27}$ See BeCK (n. 26) 135-136; NÉMETH, GY.: Erecura in Pannonia. In ARDEVAN, R. - BEUDACHIN, E. (eds): Mensa Rotunda Epigraphica Napocensis. Cluj-Napoca 2016, 71-80.

${ }^{28}$ LENDERING, J.: Herecura. In Livius.org. Articles on Ancient History (http://www.livius.org/ articles/religion/herecura/).

${ }^{29}$ CIL V 725.

${ }^{30}$ BECK (n. 26) 136, fig. 11. The inscription, $I(n) h$ (nonorem) d(omus) d(ivinae), mentions the Dea Sancta Aericura and Dis Pater (CIL XIII 6332). 
nerary aspect, like Persephone/Proserpina. The close connection of those chthonian goddesses with death can be explained by the eternal cycle of nature consisting of birth, death and renewal. ${ }^{31}$ It should be mentioned here that Eracura appears as the addressee of some Pannonian magico-religious defixiones from Carnuntum ${ }^{32}$ and from Aquincum, ${ }^{33}$ where she is mentioned as a partner of Dis Pater, and also in another love spell from Flavianae (Noricum), which invoke Pluton and Eracura, respectively identified with the chthonic Jupiter and the chthonic Iuno. ${ }^{34}$

The Angelus Bonus guiding Vibia is an element that seems to document the influx of Christian concepts. ${ }^{35}$ Following the appearance of angels beside the tomb after Christ's resurrection, or related to the liberation of the Apostles, angels appear in Paleo-Christian art as youth figures similar to that of Vibia's tomb, such as the ones from the ivory tabula from Castello Sforzesco in Milan. ${ }^{36}$

Although it has been pointed out that the mention of Septem Pii could recall the septemviri epulones, or even the banquet of the Seven Sages of Greece described by Plutarch, the number could also be explained as a reference to the Mithraic grades, since it is not impossible that Vincentius, antistes/sacerdos of Sabazius, could also have participated in other cults, as the much better known examples of Praetextatus or Faventinus show. ${ }^{37}$ The expression Manduca, vibe, lude et beni at me: cum vibes, bene fac, hoc tecum feres ("eat, drink, and be merry, and come to me, do good while you live, this you will take with you") corresponds clearly with the tradition of the pagan carmina, but the words bene fac, hoc tecum feres could imply a soteriological meaning, and when Vincentius uses the expression mente pia, he is appealing to a "language of the Christians" that seems typical of a contemporary like Paulinus of Nola. ${ }^{38}$

In presenting himself as numinis antistes Sabazis, Vincentius establishes the religious identity of the community to which he belongs. Originating from Asia Minor,

${ }^{31}$ See Green, M.: Symbol and Image in Celtic Religious Art. London - New York 2001, 41; MACKILlop, J.: Dictionary of Celtic Mythology. Oxford 2004, 4; DE VRIES (n. 19) 89; BECK (n. 26) 137.

${ }^{32}$ Adressed to Sancte Dis Pater et Veracura: EGGER, R.: Eine Fluchtafel aus Carnuntum. In EGGER, R.: Römische Antike und frühes Christentum. Bd. I. Klagenfurt 1962, 81-97. Another altar with this provenance is dedicated to Dis Pater and Aerecura (CIL III 4395).

${ }^{33}$ BARTA, A.: Ito Pater. Eracura and the Messenger. Acta Classica 51 (2015) 101-113, with references.

${ }^{34}$ NÉMETH (n. 27) 72-73, interpreting the Ito Pater mentioned in both defixiones from Aquincum (the one published by Barta in 2015 and another one still unpublished according to the information provided by Barta) as Dis Pater.

${ }^{35}$ KÁDÁR, Z.: Angelus Bonus. Acta Antiqua Hung. 41 (2001) 105-108, 108. See also SoKOLOWSKI, F.: Sur le culte d'Angélos dans le paganisme grec et romain. Harvard Theological Review, 53.4 (1960), 225-229; SHEPPARD, A. R. R.: Pagan Cults of Angels in Roman Asia Minor. Talanta 12-13 (1980-1981) 77-101; Cline, R.: Ancient Angels. Conceptualizing Angeloi in the Roman Empire. [Religions in the Graeco-Roman World 172]. Leiden-Boston 2011.

${ }^{36}$ KÁDÁR (n. 35) 106.

${ }^{37}$ VelazA (n. 10) 338. Seven characters are also depicted in the frescoes of the catacombs of Callixtus and Priscilla (see above n. 12), in these cases pointing to the episode of the banquet of the seven disciples of Christ after the episode of miraculous fishing (John 21.9ff.).

${ }^{38}$ VelaZA (n. 10) 339. 
with manifestations in the Classical Greek world and throughout the Mediterranean oikoumene in the Hellenistic and Imperial periods, Sabazius is difficult to relate to a single cultural horizon. ${ }^{39}$ As well as receiving mystery cult, the literary sources depict him with Dionysian roots, while epigraphic ones liken him to Zeus. ${ }^{40}$

The scenes in Vibia's tomb do not have explicit mystical connections. The positive outlook is demonstrated by a formula that seems to exhort enjoying the pleasures of this life (Manduca, bibe, lude), sound ethical conduct (Hoc tecum feres), and observing the deity's cult (Vincentius... sacra sancta deum menti pia coluit), without particular obligations associated with initiation. ${ }^{41}$ Far from Cumont's opinion that these frescoes expressed the beliefs of a Judaeo-Christian community which worshipped Sabazius, assimilated with Yahweh Sabaoth, ${ }^{42}$ and without going into the symbolism of a "theology of resurrection" ${ }^{43}$ implied by the panels and the hands of Sabazius, the decoration in Vibia's tomb expresses a very compact theological understanding. In it, in a single painting, Greek, Roman, and eastern elements are harmonised. The latter are represented by the figure of the cult deity and the angelus bonus, ${ }^{44}$ and by the iconography of various priests wearing the Phrygian cap, among them Vincentius. ${ }^{45}$ The judges of the afterlife belong to the Roman element, which had assimilated over a long period the mythical themes of Persephone, Hermes Psychopompus, Alcestis, and the three Parcae. It was a new and original religious reality which affirms the possibility of translating different national traditions (which nevertheless retained their own identity) in this crucible of peoples and cultures which made up the Empire and its heart, Rome. ${ }^{46}$

Although it may be a chicken and egg exercise to trace which tradition borrowed from which in the image of the meal for the departed in paradise, ${ }^{47}$ the meaning seems unambiguous. Certain pieces of furniture discovered in the catacombs may have served dining functions; underneath the church of S. Sebastiano archaeologists have found the remains of a mid-3rd-century open courtyard that must have served as

${ }^{39}$ For the Roman period, see Clem. Protr. 2. 16. 2; Arnob. Nat. 5. 2; Firm. Mat. Err. 10. 2.

${ }^{40}$ Oesterley, W. D. E.: The Cult of Sabazios. In HoOKe, S. (ed.): The Labyrinth. New York 1935, 115-158; Lane (n. 1); SotgiU, G.: Per la diffusion del culto di Sabazio. Testimonianze dalla Sardegna [EPRO 86]. Leiden 1980; TASSIGNON, I.: Sabazios dans le panthéon des cités d'Asie Mineure. Kernos 11 (1998) 189-208; GICHEVA, R.: Sabazios. In LIMC VIII/1 (1997) 1069-1071.

${ }^{41}$ SFAMENI GASPARRO (n. 20) 166.

${ }^{42}$ Cumont, F.: Les mystères de Sabazius et le judaïsme. In Comptes rendus de l'Acad. des inscr. et belles lettres 78 (1906) 63-79. In the same vein, VAN DEN HEEVER, G.: Making Mysteries. From the Untergang der Mysterien to Imperial Mysteries - Social Discourse in Religion and the Study of Religion. Religion and Theology 12 (2006) 262-307, here 272-273: "I accept that these frescoes testify to a Sabazian mystery - (Praetextatus, the owner of the property, was proconsul of Asia in 362-364, and held various priesthoods in Roman and oriental cults, including the cult of Sabazius here."

${ }^{43}$ PAILleR, J. M.: Sabazios. La construction d'une figure divine dans le monde gréco-romain. In Bonnet, C. - PirenNe-Delforge, C. - PRAET, D. (eds): Les religions orientales dans le monde grécoromain : cent ans âpres Cumont (1906-2006). Bilan historiographique. Bruxelles-Roma 2009, 257-291.

${ }^{44}$ SOKOLOWSKI (n. 35) 225-229; SHEPPARD (n. 35) 77-101; CLINE (n. 35).

${ }^{45}$ SFAMENI GASPARRO (n. 20) 166-167.

${ }^{46}$ SFAMENI GASPARRO (n. 20) 167.

${ }^{47}$ See above n. 12. 
an open-air banquet hall, and the inscriptions found at the site support the theory that this early picnic shelter was probably built to serve the faithful who came to feast in honour of Saints Peter and Paul, following the ancient pagan funerary rituals. ${ }^{48}$

On the other hand, the representation of the heavenly kingdom as a viridarium full of flowers - as seen in the frescoes in the tombs of Vibia and Vincentius - where

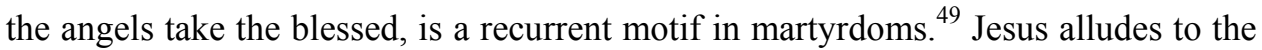
heavenly banquet in the Last Supper, according to Matthew (26.28), and the martyrs allude to the otherworldly banquet that waits for them (for example, the Martyrium Carpi, Pamphyli, Agathonices 42, ed. A. Harnack). These concepts appear in the Christian funerary prayer as well: In paradiso deducant te Angeli ....

\section{CONCLUSIONS}

The interpretation of the iconography and inscriptions in "Vibia's tomb" points to pagans and Christians sharing both funerary space and meanings, which therefore invalidates the "grand dichotomy" 51 between them in the cemeteries conventionally posed by traditional historiography. ${ }^{52}$ Attitudes are changing among scholars, and previous interpretations have been abandoned: the representation of a fish or a record of the date of death in an inscription are no longer automatically assumed to be Christian, while the dedication Dis Manibus Sacrum is no longer assumed to be pagan. ${ }^{53}$

Recently, it has been pointed out that there is very little in the sources to suggest, and nothing to confirm, that Christians and pagans could not have been buried together in the catacombs or anywhere else. Some of the few restrictive regulations were of a local nature, and what seemed important was not the place of burial, but the prayers for the soul of the deceased (for example, in Augustine's writings). ${ }^{54}$ Not only did Christian cemeteries develop from pagan burial areas (in Hadrumetum, Tipasa, Sulcis, Naples, Syracuse, Rome or even the north of Britain), but diverse catacombs and hypogaea have also provided ample evidence for mixed burials. ${ }^{55}$ This is

${ }^{48}$ JENSEN (n. 13) 56.

${ }^{49}$ Such as those of the Passio SS. Perpetuae et Felicitatis (10.11. 15 [38. $17-40.7$ ed. van Reek]) or the Passio SS. Mariani et Iacobi (6. 11-12 [139. 13-27 ed. Gebhardt]) (KÁDÁR [n. 35] 107).

${ }^{50}$ KÁDÁR (n. 35) 108.

${ }^{51}$ The expression is H. Braarbig's, referring to the radical distinction drawn by a wide section of traditional historiography between magic religion (BRAARBIG, J.: Magic: Reconsidering the Grand Dichotomy. In Jordan, D. - MonTGOMERY, H. - TOMASEN E. [eds]: Magic in the Ancient World. Papers from the first International Samson Eitrem Seminar at the Norwegian Institute at Athens, 4-8 May 1997. Bergen 1999, 21-53).

${ }^{52}$ An example of the conceptualisation of Vibia's tomb in Christian terms: MiLbURN, R.: Early Christian Art and Architecture. Berkeley - Los Angeles 1988, 45 and 57, n. 1.

${ }^{5}$ Johnson, M. J.: Pagan-Christian Burial Practices of the Fourth Century: Shared Tombs? Journal of Early Christian Studies 5.1 (1997) 37-59, here 50.

54 JOHNSON (n. 53) 48-49.

55 JOHNSON (n. 53) 52 ff. 
the case in Syracuse (catacomb of Vigna Cassia, Branciamore Hypogaeum), Agrigento, Noto Antica, and Modica.

In the city of Rome there are several examples of pagan and Christian burials in the same tombs. ${ }^{56}$ There are pagan burials at the memoria apostolorum under S. Sebastiano in the Via Appia. In St. Peter's Basilica, most of the excavated mausolea are completely pagan with only one Christian one; three of those pagan mausolea contain Christian burials, and the so-called "Mausoleum of the Egyptians" contains representations of Horus, Dionysus and Christ. It should be remembered that Sabazius has the epithet Hypsistos, and was consistently identified with Dionysus and the Jewish god, Yahweh.

The exact religious affiliation of some hypogaea is uncertain. This is the case, besides Vibia's tomb, of the Aurelii on the Viale Manzoni, the Trebius Giustus on the Via Latina, the "Cacciatori" on the Via Appia, or the famous Via Latina catacomb, discovered in $1955 .{ }^{57}$ Vibia's tomb strengthens the position that in the second half of the 4th century, there were no official Church regulations banning the burial of Christians and pagans in private cemeteries. ${ }^{58}$ In the Via Latina catacomb, datable to the 4th century and also published by Ferrua ${ }^{59}$ there are, besides Christian paintings, a representation of a reclining and partially nude woman holding an asp (Isis, Tellus, or Cleopatra in different interpretations), as well as paintings of Hercules' deeds. One scene depicts the story of him returning Alcestis to the underworld.

All this evidence implies that Roman law, still in effect in the 4th century, provided the legal basis for joint burials of people of different religious beliefs. The decoration and furnishing of private tombs corresponded to individual families or collegia and were the exclusive domain of the owners, and Christians and pagans could indeed be buried in the same tomb. The process of Christianization was gradual, and families in the 4th century were often divided between paganism and Christianity. ${ }^{60}$

Ferrua's conclusion about the little catacomb known as Vibia's tomb is clear: “(...) in questa catacomba di V1-V6 furono sepolture cristiane; cristiane e pagane dunque l'une al vicino dell'altre, senza que possiamo precisare il numéro dell'une e delle altre, o il relativo raporto (...) nell'arcosolio di Vibia e specialmente in quello dei misteri abbiamo vestiti di foggia più antica ed un certo gusto per la bella forma corporea e movimenti naturali delle figure ; ma ciò è da atribuire per una parte

${ }^{56}$ JOHNSON (n. 53) $53 \mathrm{ff}$.

${ }^{57}$ JOHNSON (n. 53) 38, n. 2, with references.

${ }^{58}$ JOHNSON (n. 53) 56.

${ }^{59}$ FerRUA (n. 1). The interpretation of these pagan iconographies in the Via Latina is controversial. While Ferrua and others read the pagan images at face value, some scholars have given a Christian interpretation on the assumption that pagans and Christians did not share the same tomb. Fink argued that Hercules had been assimilated to Christ, in a similar adaptation to those of Orpheus or Ulysses in some catacombs. But, as Wright and Simon have noted, the representations of Hercules are confined to two cubicles devoid of any Christian symbols, which makes this assimilation problematic (JOHNSON [n. 53] 58).

${ }^{60}$ JOHNSON (n. 53) 58-59. 
a tradizione per cosí dire liturgica che esigeva in tali azioni l'uso di abiti antichi se ormai fuori moda nella vita, e dall'altra al ritorno del gusto classico che si verifica verso la méta del sec. IV."6

In a hypogaeum shared by "pagans" and Christians, Vibia's tomb is an outstanding example of a space of mystic religiosity. This place combines epigraphy and a fascinating iconography pointing to the mystic initiation of the deceased within a syncretic context, comparable to that of the inscriptions mentioning prominent figures of the pagan aristocracy of the 4th century such as Vettius Agorius Praetextatus, the supposed owner of Vibia's tomb according to some scholars, Aradius Valerius Proculus, Celius Hilarianus, Ulpius Egnatius Faventinus, Alfenius Ceionus Iulianus Kamenius and Ceionius Rufius Volusianus, all of whom were senators. ${ }^{62}$

It has been pointed out that what characterised the changes experienced by the Roman Empire in the 3rd century was not so much Dodd's "anxiety" as a religious ferment expressed through intellectuals focused on religious topics. ${ }^{63}$ In the same trend, Peter Brown has underlined the importance of writings and textuality, together with the intellectual fervour and the theological and metaphysical implications of many Late Antique figures. ${ }^{64}$ What the archaeological information provides is not so much a conversion, but multiple adhesions ${ }^{65}$ within a traditional "empiric epistemology" which maintained the ancestral traditions, ${ }^{66}$ combining them with a personal choice to join initiation cults. The images and texts from the tomb of Vibia and her husband Vincentius constitute, as it were, an example of the "middle grounds qui stimulant l'attention des historiens, c'est-à-dire les situations de transaction, négociation, cohabitation, ou encore de compromise qui aident à penser les mutations religieuses, avec ce qu'elles impliquent d'approche empirique et de bricolage". ${ }^{67}$ All this

${ }^{61}$ FERRUA (n. 1) 58 and 60.

${ }^{62}$ MARCO SIMÓN, F.: Vetio Agorio Pretextato y el fervor universalista de la religion tradicional. In MARCo SimÓn, F. - PinA Polo, F. - ReMesal RodrígueZ, J. (eds): Autorretratos. La creación de la imagen personal en la Antigüedad. Barcelona 2016, 213-226, with references. Examples of dedications in the Vatican Phrygianum between 370 and 390, including metroac initiations as well as priesthoods that coexist with other cults, both Roman and Eastern, in CAMERON, A.: The Last Pagans of Rome. Oxford 2011, 144-146, 149.

${ }^{63}$ Rouselle, A. - CARré, J. M.: Nouvelle Histoire de l'Antiquité. Tome 10: L'Empire Romain en mutation. Des Sévères à Constantin. Paris 1999, 436-437.

${ }^{64}$ Brown, P.: Concluding Remarks. In BROwn, P. - Lizzi TeStA, R. (eds): Pagans and Christians in the Roman Empire: The Breaking of a Dialogue (IVth-VIth Century AD. Proceedings of the International Conference at the Monastery of Bose (October 2008) Zurich-Berlin 2011, 599-608, here 604-608.

${ }^{65}$ A good review of these questions may be found in RIVES, J. B.: Religious Choice and Religious Change in Classical and Late Antiquity: Models and Questions. ARYS: Antigüedad, religiones y sociedades 9 (2011) 265-280, based on the model established by NocK, A. D.: Conversion: The Old and the New in Religion from Alexander the Great to Augustine of Hippo. Oxford 1933. The contexts of adhesion are characterised by a variety of ethnic and cultural traditions, and a multiplicity of overlapping discourses with limited truth claims, while the contexts of conversion imply all-encompassing systems which are mutually exclusive (RIVES 271).

${ }^{66}$ ANDO, C.: The Matter of the Gods: Religion and the Roman Empire. [The Transformations of the Classical World 44]. Berkeley 2008, 13.

${ }^{67}$ BONNET, C. - BRICAULT, L.: Introduction. In BRICAULT-BONNET (n. 15) 1-14, here 13. 
can be detected in the epigraphy of prominent figures in the 4th century, and all this seems to be found in complexes as fascinating as the so-called "Vibia's tomb", where the pax deorum and not the strife of the gods is revealed.

Francisco Marco Simón "Hiberus" Research Group Universidad de Zaragoza Spain 